\title{
Growth factors in developed countries: A 1960-2019 growth accounting decomposition
}

\author{
Gilbert Cette *, Aurélien Devillard † \\ and Vincenzo Spiezia
}

\author{
October 2020, WP \# 783
}

\begin{abstract}
Using a new and original database, our paper contributes to the growth accounting literature with three original aspects: first, it covers a long period from the early 60's to 2019, just before the COVID-19 crisis; second, it analyses at the country level a large set of economies (30); finally, it singles out the growth contribution of ICTs but also of robots. The original database used in our analysis covers 30 developed countries and the Euro Area over a long period allowing to develop a growth accounting approach from 1960 to 2019. This database is built at the country level. Our growth accounting approach shows that the main drivers of labor productivity growth over the whole 1960-2019 period appear to be TFP, non-ICT and non-robot capital deepening, and education. The overall contribution of ICT capital is found to be small, although we do not estimate its effect on TFP. The contribution of robots to productivity growth through the two channels (capital deepening and TFP) appears to be significant in Germany and Japan in the sub-period 1975-1995, in France and Italy in 19952005, and in several Eastern European countries in 2005-2019. Our findings confirm also the slowdown in TFP in most countries from at least 1995 onwards. This slowdown is mainly explained by a decrease of the contributions of the components 'others' in the capital deepening and the TFP productivity channels.
\end{abstract}

Keywords: Growth, Productivity, ICTs, Robots JEL classification: O31, O33, O47

\footnotetext{
*Banque de France and AMSE, gilbert.cette@banque-france.fr

${ }^{+}$AMSE, devillardaurelien@gmail.com

‡OECD, vincenzo.spiezia@oecd.org
}

The views expressed in this paper are those of the authors and should not be interpreted as reflecting the views of the Banque de France, the AMSE or the OECD. This document is available on publications.banque- 


\section{NON-TECHNICAL SUMMARY}

One paradox has appeared over the last decades: in the developed countries, and whatever their individual development level, we observe at the same time a continuous productivity slowdown and an increase of the diffusion of ICTs and robots, and even the emergence of the use of digital technologies. This paradox has not yet received any consensual explanation. The aim of this study is to raise some characteristics of such a paradox. By developing a new database, it contributes to the growth accounting literature with three original aspects: first, it covers a long period from the early 60's to 2019, just before the COVID-19 crisis; second, it analyses at the country level a large set of economies (30); finally, it singles out the growth contribution of ICTs but also of robots, which, following the SNA definition, is bundled in non-ICT capital.

The original database used in our analysis covers 30 developed countries ${ }^{1}$ and the Euro Area over a long period allowing us to develop a growth accounting approach from 1960 to 2019. This database is built at the country level and contains several variables such as GDP, hours worked (employment and average working time), ICT and non-ICT capital, number of robots and education level. As much as possible, each of these variables is built in a harmonized methodology for all countries. Several sources were used to build this database, assuming explicitly some usual assumptions.

Results of growth accounting decomposition for the Euro Area GDP growth (in \%) and contributions (in pp)

\begin{tabular}{|c|c|c|c|c|c|}
\hline GDP growth (in \%) and contributions (in pp) & Period 1 & Period 2 & Period 3 & Period 4 & Period 5 \\
\hline ZONE EURO 2 & $1960 \quad 1975$ & $1975 \quad 1995$ & $1995 \quad 2005$ & $2005 \quad 2019$ & $1960 \quad 2019$ \\
\hline GDP (1) & 4,60 & 2,44 & 2,12 & 1,09 & 2,61 \\
\hline Hours (2) & $-0,71$ & $-0,22$ & 0,93 & 0,37 & $-0,01$ \\
\hline Productivity (3) = (1)-(2) & 5,31 & 2,66 & 1,19 & 0,72 & 2,63 \\
\hline Capital deepening (4) & 2,03 & 0,97 & 0,43 & 0,42 & 1,02 \\
\hline ICT capital total $(5)=(6)+(7)+(8)$ & 0,17 & 0,23 & 0,24 & 0,14 & 0,19 \\
\hline Hardware (6) & 0,11 & 0,12 & 0,11 & 0,03 & 0,09 \\
\hline Software and databases (7) & 0,03 & 0,09 & 0,10 & 0,09 & 0,08 \\
\hline Telecommunication eqpt (8) & 0,03 & 0,02 & 0,03 & 0,02 & 0,03 \\
\hline Robots (9) & 0,00 & 0,03 & 0,08 & 0,05 & 0,04 \\
\hline Non ICT capital and non robots capital $(10)=(4)-(5)-(9)$ & 1,86 & 0,71 & 0,11 & 0,24 & 0,79 \\
\hline $\operatorname{TFP}(11)=(3)-(4)$ & 3,28 & 1,69 & 0,77 & 0,30 & 1,61 \\
\hline Education (12) & 0,59 & 0,38 & 0,21 & 0,31 & 0,39 \\
\hline Robotisation (13) & 0,01 & 0,08 & 0,24 & 0,15 & 0,12 \\
\hline Residual (14) = (11)-(12)-(13) & 2,68 & 1,23 & 0,32 & $-0,16$ & 1,10 \\
\hline
\end{tabular}

Source: Authors' calculations.

Our growth accounting approach shows that the main drivers of labor productivity growth over the whole 1960-2019 period appear to be TFP, non-ICT non-robot capital deepening and education. The overall contribution of ICT capital is found to be small, although we do not estimate its effect on TFP. The contribution of robots to productivity growth through the two channels (capital deepening and TFP) appears to be significant in Germany and Japan in the sub-period 1975-1995, in France and Italy in 1995-2005, and in several Eastern European countries in 20052019. Our findings confirm also the slowdown in TFP in most countries from at least 1995 onwards. This slowdown is mainly explained by a decrease of the contributions of the components 'others' in the capital deepening and the TFP productivity channels.

1 These countries are: Australia, Austria, Belgium, Canada, the Czech Republic, Denmark, Estonia, Finland, France, Germany, Greece, Hungary, Ireland, Israel, Italy, Japan, Lithuania, Luxembourg, Latvia, Mexico, The Netherlands, Norway, New Zealand, Portugal, Slovakia, Slovenia, Spain, Sweden, the United Kingdom and the United States. 
We are still waiting for a large productivity benefit from the third industrial revolution: the digital one. We know from previous industrial revolutions that it may take decades to get a large productivity benefit at the global level from promising inventions and innovations. If we extrapolate that, it could take a long time for the full impact of the digital revolution to be felt in productivity statistics at the global level. If this explanation is the right one, we could benefit in some years or decades from a dramatic productivity revival. Otherwise, developed countries would face with difficulties the numerous challenges of the future.

\title{
Les facteurs de la croissance dans les pays avancés : Une décomposition comptable sur la période 1960-2019
}

\begin{abstract}
RÉSUMÉ
Mobilisant une base de données originale, cette analyse contribue à la littérature sur les analyses comptables de la croissance avec trois originalités. Tout d'abord, elle couvre une longue période s'étendant de 1960 à 2019, juste avant la crise ouverte par la pandémie COVID-19. Ensuite, elle est menée au niveau de l'ensemble de l'économie d'un grand nombre de pays avancés (30) et de la zone euro. Enfin, elle caractérise les contributions à la croissance des technologies de l'information et de la communication (TIC) mais aussi de la robotisation. Les résultats de cette analyse montrent que les principaux facteurs de croissance sur l'ensemble de la période 1960-2019 seraient la productivité globale des facteurs (PGF), la substitution au travail du capital hors TIC et hors robots, et l'éducation. La contribution du capital TIC serait faible, même si l'analyse ne caractérise pas l'impact de ces technologies sur la PGF. La contribution de la robotisation à la croissance de la productivité (au travers des deux canaux de la PGF et de la substitution capital-travail) apparait forte en Allemagne et au Japon dès la sous-période 1975-1995, en France et en Italie à partir de la sous-période 1995-2005, et dans plusieurs pays de l'Est européen après 2005. Les résultats obtenus confirment aussi le ralentissement généralisé de la PGF à partir de 1995 ou même auparavant. Ce ralentissement est principalement expliqué par la baisse des contributions des composantes 'autres' au sein des composantes de la croissance de la PGF et de la substitution capital-travail.
\end{abstract}

Mots-clés : croissance, productivité, TIC, robots

Les Documents de travail reflètent les idées personnelles de leurs auteurs et n'expriment pas nécessairement la position de la Banque de France, de l'AMSE de l'OCDE. Ils sont disponibles sur publications.banque-france.fr 


\section{Introduction}

Since the seminal analyses from Solow ${ }^{1}$, growth accounting is the most widely used approach to measure the contribution of factors to productivity growth. Over the last decades, this approach has been used to evaluate the contribution of Information and Telecommunication Technologies (ICTs) to growth. It consists in decomposing the growth of value added per hour worked (labor productivity) into the growth of ICT capital and non-ICT capital per hour worked, based on a set of input-specific elasticities.

Early studies on the impact of ICTs on productivity yielded largely inconclusive results. The well-known Solow paradox for which "computers are visible everywhere except in productivity statistics" summarises the state of art in the early 1990s. The lack of correlation between ICT investment and productivity growth was mostly due to incorrect measurement of ICT capital prices and quality. Significant improvements in the measurement of ICT capital (OECD, 2001 and 2009) have opened the way to a new stream of analysis on the growth effects of ICTs. According to OECD (2019), the yearly contribution of ICT capital to labor productivity in a set of 23 OECD countries over 1995-2017 ranged between 0.66 percentage points a year in New Zealand to 0.25 percentage points in Finland. The average yearly contribution, however, decreased from 0.42 percentage points in 2001-07 to 0.25 percentage points in 2010-17.

But one paradox has appeared over the last decades: in the developed countries, and whatever their individual development level, we observe at the same time a continuous productivity slowdown and an increase of the diffusion of ICTs and robots, and even the emergence of the use of digital technologies. This paradox has not yet received any consensual explanation (for a literature review, see Bergeaud, Cette and Lecat, 2019). The aim of this study is to raise some characteristics of such a paradox. By developing a new database, it contributes to the growth accounting literature with three original aspects: first, it covers a long period from the early 60's to 2019, just before the COVID-19 crisis; second, it analyses at the country level a large set of economies (30); finally, it singles out the growth contribution of ICTs but also of robots which, following the SNA definition, is bundled in non-ICT capital.

The original database used in our analysis covers 30 developed countries ${ }^{2}$ and the Euro Area over a long period allowing us to develop a growth accounting approach from 1960 to 2019. This database is built at the country level and contains several variables such as GDP, hours worked (employment and average working time), ICT and non-ICT capital, number of robots and education level. As much as possible, each of these variables is built in a harmonized methodology for all countries. Several sources were used to build this database, assuming explicitly some usual assumptions.

Our growth accounting approach shows that the main drivers of labor productivity growth over the whole 1960-2019 period appear to be TFP, non-ICT non-robot capital deepening and education. The overall contribution of ICT capital is found to be small, although we do not estimate its effect on TFP. The contribution of robots to productivity growth through the two channels (capital deepening and TFP) appears to be significant in Germany and Japan in the sub-period 1975-1995, in France and Italy in 1995-2005, and in several Eastern European countries in 2005-2019. Our findings confirm also the slowdown in TFP in most countries from at least 1995 onwards. This slowdown is mainly explained by a decrease of the contributions of the components 'others' in the capital deepening and the TFP productivity channels. While several contributions have recently addressed this issue (see below) further analysis appears necessary to explain the cause of such slowdown.

1 See for instance Solow $(1956,1957,1959,1962)$.

2 These countries are: Australia, Austria, Belgium, Canada, the Czech Republic, Denmark, Estonia, Finland, France, Germany, Greece, Hungary, Ireland, Israel, Italy, Japan, Lithuania, Luxembourg, Latvia, Mexico, The Netherlands, Norway, New Zealand, Portugal, Slovakia, Slovenia, Spain, Sweden, the United Kingdom and the United States. 
The paper is organized a follows. Section 2 provides a brief review of previous studies. Section 3 presents the data and the methodology of the analysis. Section 4 examines the main trends in the diffusion of ICT capital and robots. The findings of the growth accounting analysis are presented in Section 5 while Section 6 concludes.

\section{A review of previous studies}

Since the early 2000s, numerous papers have highlighted the significant contribution of new technologies to productivity growth. We identify below only some of them among the most contributive ones.

Numerous analyses focus attention on the ICT contribution to growth. Main results from them are that i) the contribution of ICT to growth became significant and increased from the 1980s to stabilize or even decrease from the 2000s, ii) large developed countries are lagging compared to the US in terms of ICT diffusion and ICT contribution to growth. Jorgenson and Stiroh (2000) apply Jorgenson's production possibility frontier to explain productivity growth in the United States after 1995. They find that the fall in ICT prices and the increase TFP were the main factor accounting for higher growth in average labor productivity in 1995-99. Based on a Solow-like growth accounting model, Oliner and Sichel (2000, 2002) find out that the contribution of ICT capital in the United States increased between the periods 1974-95 and 1996-99 and that TFP growth also increased by 40\% in the period 1996-99. Based on a sample of nine OECD countries, Colecchia and Schreyer (2002) find that ICT contributed between 0.2 and 0.5 percentage points per year to economic growth over 1980-2000, with the largest effects in the United States followed by Australia, Finland and Canada. Using US producer price indices as a deflator for ICT investment, Oulton (2002) finds that the ICT contribution to GDP growth in the UK increased from $13.5 \%$ in $1979-89$ to $20.7 \%$ in $1989-98$. ICTs accounted for $55 \%$ of capital deepening during the period 1989-98 and 90\% in the period 1994-98. Crepon and Heckel (2002) estimate that, over the period 1987-98, ICTs accounted for 0.7 percentage points of the yearly value added growth in France, 0.3 points from capital deepening and 0.4 points from TFP growth in ICT-producing industries. Van Ark et al. (2002) analyze the different impact of ICTs on productivity between the United States and Europe over the period 1980-2000. They find that, while the pattern of ICT diffusion in Europe has not been much different from that in the United States, EU countries started from much lower stocks of ICT capital. As a result, the contribution of ICTs to productivity growth have been lagging behind the United States. O'Mahony and Vecchi (2005) estimate the impact of ICT capital on output growth using a dataset of US and UK non-agricultural market industries. Pooled estimates show a positive and significant return of ICT capital on output growth, above the prediction from growth accounting. Individual countries' estimates suggest a larger long-run impact in the US than in the UK. Timmer et al. (2010) provide a detailed analysis of the sources of growth from a comparative industry perspective. Their findings suggest that Europe's slow growth is the combined result of a severe productivity slowdown in traditional manufacturing and low ICT investment in market services. Spiezia (2012) estimates that the contribution of ICT investments to value added growth in the business sector over 1995-2007 varied from $1.0 \%$ a year in Australia to $0.4 \%$ a year in Japan. ICT producing industries accounted for no less than two-thirds of TFP growth in Germany, Slovenia and the UK, about 60\% in the US and just below $50 \%$ in France and The Netherlands. Cette et al. (2015) show that ICT diffusion is lagging in the Euro area, Canada, the UK and Japan compared to the US and that in these countries ICT contribution to growth has stopped to increase or have even has decreased from the early 2000 s.

Several analyses as for instance O'Mahony and Vecchi (2005) emphasise the complexity of the link from technology to productivity. To leverage ICT investment successfully, firms must typically make large complementary investments and innovate in areas such as business organisation, workplace practices, human capital and intangible capital.

The role of intangible capital and its interaction with ICT concerning its impact on productivity is highlighted in numerous analyses. Corrado et al. (2006) incorporate intangible assets into a macro growth accounting framework. The inclusion of intangibles results into a lower contribution of TFP to 
labor productivity as well as a larger contribution of capital deepening and other factors typically associated with the knowledge economy. Corrado et al. (2020) develop a theoretical framework to analyse the relationship among intangibles, innovation, and productivity by building a Jorgenson-like model of economic growth. They also provide empirical evidence for the US plus a sample of European countries. They show that the growth of intangible capital recovers faster after the Great Recession than that of tangible capital, and that there is a positive relationship between intangible and ICT capital growth and TFP growth, whereby the decline in intangible capital growth explains the decline of TFP growth more in the US than in Europe.

The increasing contribution of robots to productivity growth is shown in a growing literature, and for instance on French firm level data by Acemoglu, Lelarge and Restrepo. (2020) or by Graetz and Michaels $(2015,2018)$ on a country-industry dataset. But even if the impact of robot adoption appears large at the firm level, these analyses show that it stays small and for instance far below that of the ICT at the country level.

The productivity slowdown observed in developed countries over the last decades (see Bergeaud et al. 2016, 2017) and its explanatory factors are analysed also in a growing literature. Through growth accounting approaches, Bergeaud et al. (2018) show that the end of the diffusion of innovations linked to the second industrial revolution and the end of the long increase in the average education level of the working age population contribute only partly to the productivity slowdown. And Bergeaud et al. (2019) show that the general decrease of real interest rates contributes also but only in a small way to the productivity slowdown. Inklaar et al. (2020) analyse the supply factors of the European growth compared to the US between 1995 and 2015. They show that both in Europe and in the US, ICTs have significantly contributed to productivity growth, but they admit not to be able to explain the general productivity slowdown. It seems to them that we are still «in the midst of the transition from the Old Digital Economy (which was characterized by the introduction of the PC in people's lives and business processes, the rise of the Internet, and the beginning of the e-commerce) to the New Digital Economy (which is characterized by the change toward mobile, ubiquitous access to the Internet, the storage and usage of data, and advances in artificial intelligence and robotics) ». The general productivity slowdown has not yet received a consensual explanation.

\section{Data and growth accounting methodology}

\subsection{Data}

To carry on our growth accounting evaluation, we need data concerning GDP, hours, capital and user cost of capital, education and robots. Except for some which are mentioned to be built on a longer period, all data are built from 1951-2019. For data in constant price, the year base is 2015. These data are built for each of the 30 countries of the analysis (see the list of these countries in the introduction). Euro Area has been reconstituted, aggregating Germany, France, Italy, Spain, The Netherlands, Belgium, Austria, Finland, Greece, Ireland, and Portugal, these 11 countries representing together, in 2018, 97\% of the Euro Area GDP.

Data concerning the GDP in current value come from several databases: BEA for the USA, Eurostat, OECD, Penn World Tables 9.1, and ONU. Sources concerning the GDP deflator are the BEA for USA, INSEE for France, Eurostat, OECD and Penn World Table 9.1 for all other countries. It has been extrapolated from 1950 to 1989 for Czech Republic, Estonia, Lithuania, Latvia, Slovakia, Slovenia and to 1969 for Hungary, using the growth rate of a similar country. GDP in constant 2015 value results from the ratio of the GDP in current value by the GDP deflator.

The number of hours worked is the average annual working time per worker multiplied by the employment. The sources of these two indicators are LongTermProductivity database (LTP here after), OECD, TED (Total Economy Database). The LTP database contains data from 1950 for the following countries: Australia, Austria, Belgium, Canada, Germany, Denmark, Spain, Finland, France, United 
Kingdom, Greece, Israel, Italia, Japan, Mexico, Netherlands, Norway, New-Zealand, Portugal, Sweden and USA. For the other countries, we use OECD and TED. The working time per worker is extrapolated for Czech Republic, Estonia, Hungary, Israel, Lithuania, Luxembourg, Latvia, Slovakia and Slovenia from 1950 to 1994 at the latest using the growth rate of a similar country.

The total stock of capital in constant price is computed with data from the LTP database for the countries available in this base, and for the other countries we use the Penn World table and Ameco. In the LTP database, the stock of capital in constant price is built separately for equipment and buildings through a permanent inventory model (PIM hereafter), the yearly depreciation rates being $10.0 \%$ for equipment and $2.5 \%$ for buildings and being assumed to be constant across time and space (see Bergeaud et al., 2016, 2017).

The ICT capital stock in constant price is built through a PIM applied on investment in constant price data, for each of the three ICT products: hardware, software and telecommunication equipment. For telecommunication equipment the initialization starts in 1931, and it starts in 1951 for the two other products. As in previous analyses, the yearly depreciation rates are 0.3 for hardware and software and 0.15 for telecommunication equipment (see for instance Cette, Clerc and Bresson, 2015, or Cette, Lopez and Mairesse, 2017). The investment in constant price is calculated by the ratio of the investment in current price and the corresponding deflator. Data concerning ICT Investment in current price were provided by the OECD in 3 series, respectively revised in 1993, before 2019 and after 2019 for each of the three ICT products with partially available data. From 1950 (1930 for telecommunication equipment) to 1959 , we build data for all countries supposing that the investment rate (investment in value divided by the GDP in value) is constant. This method is used on a longer period, until 2004 at the latest, for Czech Republic, Estonia, Hungary, Israel, Lithuania, Latvia, Mexico, Slovakia and Slovenia. For Austria, Portugal and Greece we also build data from 1960 to 1994: we compute the investment rate of the country in 1995, and we suppose that it follows the evolution of the investment rate of a similar country for the past years, respectively Germany, Spain and Italy.

Concerning the deflators of ICT investment, for each of the three ICT product we use for the US the one computed by the Bureau of Economic Analysis (BEA). For the other countries, and as in numerous other analyses (as for instance the same analyses than those mentioned before), we use a method suggested by Schreyer (2000): it supposes that the relative price ratio of investment to GDP is the same than in the USA.

Nominal long-term interest rates correspond to sovereign 10 year bonds. The primary source of data is the OECD Main Economic Indicators (OECD, 2018) which we backdate using the Macrohistory database constructed by Jordà et al. (2019), International Financial Statistics, Eurostat and Ameco databases for Austria, Czech Republic, Estonia, Greece, Hungary, Ireland, Israel, Lithuania, Luxembourg, Latvia, Mexico, New-Zealand, Slovakia and Slovenia, we build data using the nominal interest rate of a reference country, and we add the difference of growth rate of the GDP deflator of both countries.

Education corresponds to the average number of years of schooling of the population aged 25 and more. We use for that series of educational attainment provided by van Leeuwen and van Leeuwen-Li (2014) updated by Bergeaud et al. (2018), with data from the UNESCO and the Penn World Table 9.1.

The source of data concerning robots is the International Federation of Robots (IFR), covering the installation and the operational stock of robots from 1983 to 2019, with partially available data. We consider the industrial robots, corresponding to the definition of the International Organization for Standardization: an "automatically controlled, reprogrammable multipurpose manipulator programmable in three or more axes" (Presidente, 2019). To complete and extend this database from 1960, we use the results of an OLS regression estimating the stock of robots based on the evolution of the stock of each of the three ICT products (hardware, software and telecommunication), with fixed 
effects for countries and a common trend. This method has been privileged after robustness tests made with other regressions. ${ }^{3}$

\subsection{Growth accounting methodology}

The contribution to labor productivity growth of the capital deepening in total capital and in each ICT component is estimated by applying the growth accounting methodology suggested by Solow (1956, 1957). ${ }^{4}$ For each of these four scopes (the index is excluded for to simplify notations), the contribution of capital to labor productivity growth in year $t$, noted as $C K_{t}$, is evaluated through the following relation:

$C K_{t}=\alpha_{T, t} \cdot\left(\Delta k_{t-1}-\Delta n_{t}-\Delta h_{t}\right)$

where $K_{t-1}$ corresponds to the capital installed at the end of year $t-1, N_{t}$ refers to total employment in year $t$, and $H_{t}$ designates the average annual hours worked per person per year $t$. The notation of the variables in lowercase corresponds to their natural $\log (x=\ln (X))$, and the growth rate of a variable is approximated by the variation of its logarithm. The $\Delta$ symbol refers to the variation of a variable $\left(\Delta X_{t}=X_{t}-X_{t-1}\right)$.

Concerning the global stock of capital, the coefficient $\alpha_{T, t}$ is assumed to be constant over time and the same in all countries, and equal to $0.3\left(\alpha_{T, t}=0.3\right) .^{5}$

Concerning each of the three ICT components, the coefficient $\alpha_{T, t}$ is the Törnquist index of the coefficient $\alpha_{t}$ :

$\alpha_{T, t}=\left(\alpha_{t}+\alpha_{t-1}\right) / 2$.

The coefficient $\alpha_{t}$ corresponds to the share of the capital remuneration (remember that this is calculated for each ICT product) in the GDP:

$\alpha_{t}=\left(C_{t} \cdot K_{t-1}\right) /\left(P Q_{t} \cdot Q_{t}\right)$

where $C_{t}$ corresponds to the user cost of capital, $K$ refers to the capital stock in volume, $P Q$ corresponds to the GDP deflator, and $Q$ refers to GDP in volume.

The user cost of capital $C$ is calculated employing the relation proposed by Jorgenson (1963):

$C_{t}=P_{t} \cdot\left(i_{t}+\delta+\Delta p_{t}\right)$

where $P$ corresponds to the investment price of the ICT product, $i$ refers to the long term nominal interest rate, and $\delta$ designates the assumed invariant depreciation rate of the ICT product.

3 Detailed results of these econometric estimates are available upon request from the authors.

4 This decomposition assumes that the production function can be approximated by a Cobb-Douglas function with constant returns to scale.

5 As it is the case here concerning the three ICT capital components, it is generally assumed that production factors are remunerated at their marginal productivity (at least over the long term, which is the horizon of the study), which means that it is possible to estimate factor elasticities on the basis of the share of their remuneration (cost) in total income (or total cost). Concerning the global stock of capital, given that labor costs (wages and related taxes and social security contributions) represent roughly two-thirds of income, it is simply assumed here that $\alpha=0.3$. It appears that the results of the study are robust to this calibration of $\alpha$ and remain roughly stable for other realistic values (see Bergeaud et al., 2016, 2018). 
Concerning the impact of education on labor productivity, we use here the results from Bergeaud et al. (2018) estimated on a panel of 17 developed countries, which are totally consistent with those from other analyses as for instance Barro and Lee (2010), Soto (2002) or Krueger and Lindahl (2001). It corresponds to a calibration of a 5\% labor productivity increase for one more year of average schooling.

Concerning the impact of robots on labor productivity, we use here the results from Graetz and Michaels $(2015,2018)$ estimated on a panel of 14 developed countries, which seem consistent (as far as the comparison is possible) to the ones of Acemoglu et al. (2020) estimated on a panel of French firms.

Based on the estimates by Graetz and Michaels $(2015,2018)$, we have $i$ ) set the elasticity of labor productivity to the number robots per hours worked to 0.144 ; $i$ i) broken down the robots' contributions to labor productivity into a) an increase in the stock of capital per hours worked (24\%) and b) an increase in TFP $(76 \%)$. The above elasticity being estimated on the set of sectors using robots, we have weighted its effect by the share of those sectors in the total value added in each country.

In this way, we are able to single out the contribution of robots, which are included in the stock of nonICT capital, to labor productivity growth through two channels: capital deepening and TFP. ICT capital, on the other hand, has been found orthogonal to the number of robots (Cette, Lopez, Presidente and Spieza, 2019).

\section{ICT and Robot diffusion}

\subsection{ICT diffusion}

The ICT diffusion is here evaluated with the ICT capital coefficient in current prices, which corresponds to the ratio (in percentage) of the ICT capital and the GDP in current prices.

The evolution of the ICT capital diffusion over the period 1960-2019 seems to follow the same type of path in the ten largest countries (or area) of our dataset (Chart 1). We can distinguish three phases. First, a slow increase during two decades, until the early 1980s. This phase corresponds to the progressive start of the ICT diffusion. Second, a rapid increase during the two following decades, until the beginning of the current century. This phase corresponds to the golden age of ICT diffusion and to the strong development in the use of these productive technologies. Third, a stabilization or even a decrease in some countries such as United Kingdom, Japan, Canada or Germany, during the last two decades. The ICT capital coefficient continues to increase during this third sub-period in a few countries such as France, Spain and the Netherlands.

In the main countries and areas, the ICT capital coefficient reaches a maximum at the beginning of the 2000 s. The peak at the beginning of the 2000s signifies a spurred investment effort associated with the fear of Y2K. The stability of the nominal ICT capital coefficient since the beginning of the 2000s has already been observed by Cette and Lopez (2012) or Cette et al. (2015). Our study confirms this result and shows that the stagnation persists during and after the Great Recession: the diffusion of ICT as a factor of production appears to stabilize for about two decades. The ICT capital coefficient in current prices stabilizes at different levels depending on the country. ICT diffusion in the United States settles at a level equivalent to Japan, France and the Netherlands, and higher than in the other countries. The lag of ICT diffusion is considerable for some countries. By 2019, the United States has an ICT capital coefficient that is $40 \%$ higher than for the Euro Area and Canada and even $80 \%$ higher than for the United Kingdom. Furthermore, earlier analyses support this hierarchy of ICT diffusion. ${ }^{6}$

Numerous studies provide explanations for these international differences in ICT diffusion, including the level of post-secondary education among the working age population as well as labor and product

6 See for instance van Ark et al. (2008), Timmer et al. (2011), Cette and Lopez (2012) or Cette et al. (2015). 
market rigidities. For example, an efficient use of ICT requires a higher degree of skilled labor than the use of other technologies. The required reorganization of the firm for effective ICT adoption can be constrained by strict labor market regulations. Moreover, low levels of competitive pressure resulting from product market regulations can reduce the incentive to exploit the most efficient production techniques. A large number of empirical analyses have confirmed the importance of these factors. ${ }^{7}$ Quite simply, the United States benefits from a high level of ICT diffusion because of a high level of postsecondary education among the working age population and few restrictive product and labor market regulations.

The stability of the ICT capital coefficient in current prices from the early 2000 s is consistent with a continuous increase of the ICT capital coefficient in constant prices, considering the decrease of the ICT price relative to the GDP price by $2 \%$ on average per year from 2000 to 2019 . But it has not the same meaning in terms of ICT diffusion.

\section{Chart 1}

ICT Capital Coefficient, 1960-2019

\section{Ratio of ICT capital stock to GDP in current prices, \%}

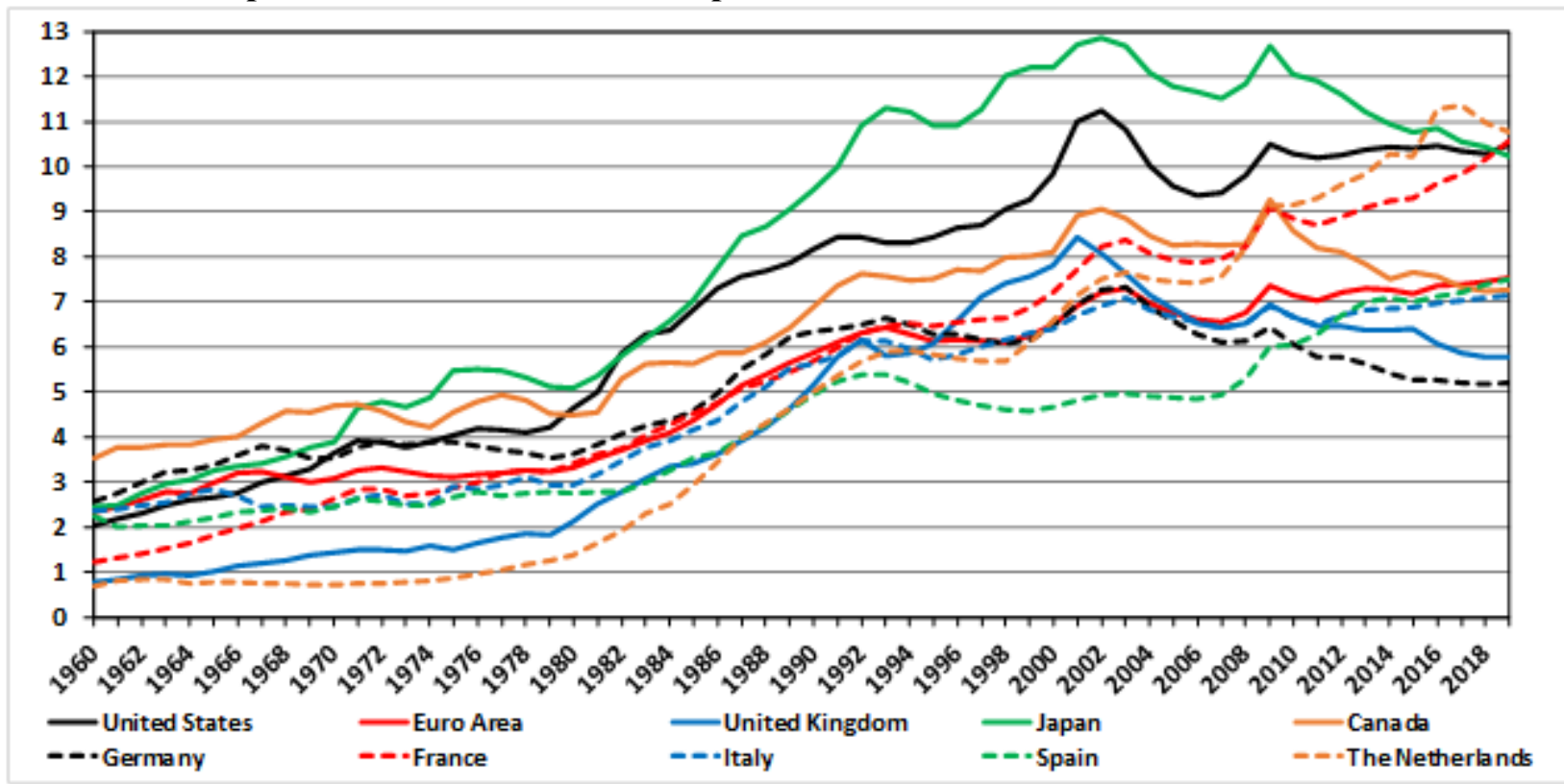

Source: Authors' calculations.

ICT diffusion differs a lot in 2019 between countries over our complete set of 31 countries and areas (Chart 2). It is by far the highest in Sweden, with a capital coefficient superior to $14 \%$, the following country being New Zealand, 2pp below. The ICT capital coefficient is superior to $10 \%$ in 8 countries: Sweden, New Zealand, Czech Republic, Austria, The Netherlands, United States, France and Japan. In contrast, it is inferior to 5\% in five countries: Lithuania, Hungary, Ireland ${ }^{8}$, Mexico and Slovakia. Other countries, including the Euro Area considered as a whole, are in an intermediate situation. The three ICT products (hardware, software and communication equipment) contribute to these differences.

7 See Aghion et al. (2009), Guerrieri et al. (2011) and Cette and Lopez (2012) who use country-level panel data, as well as Cette et al. (2017) who employ sectoral-level panel data.

8 For Ireland, we cannot exclude that this low ICT capital diffusion could correspond more to measurement problems than to reality. 


\section{Chart 2}

ICT Capital Coefficient, 2019

Ratio of ICT capital stock to GDP in current prices, \%

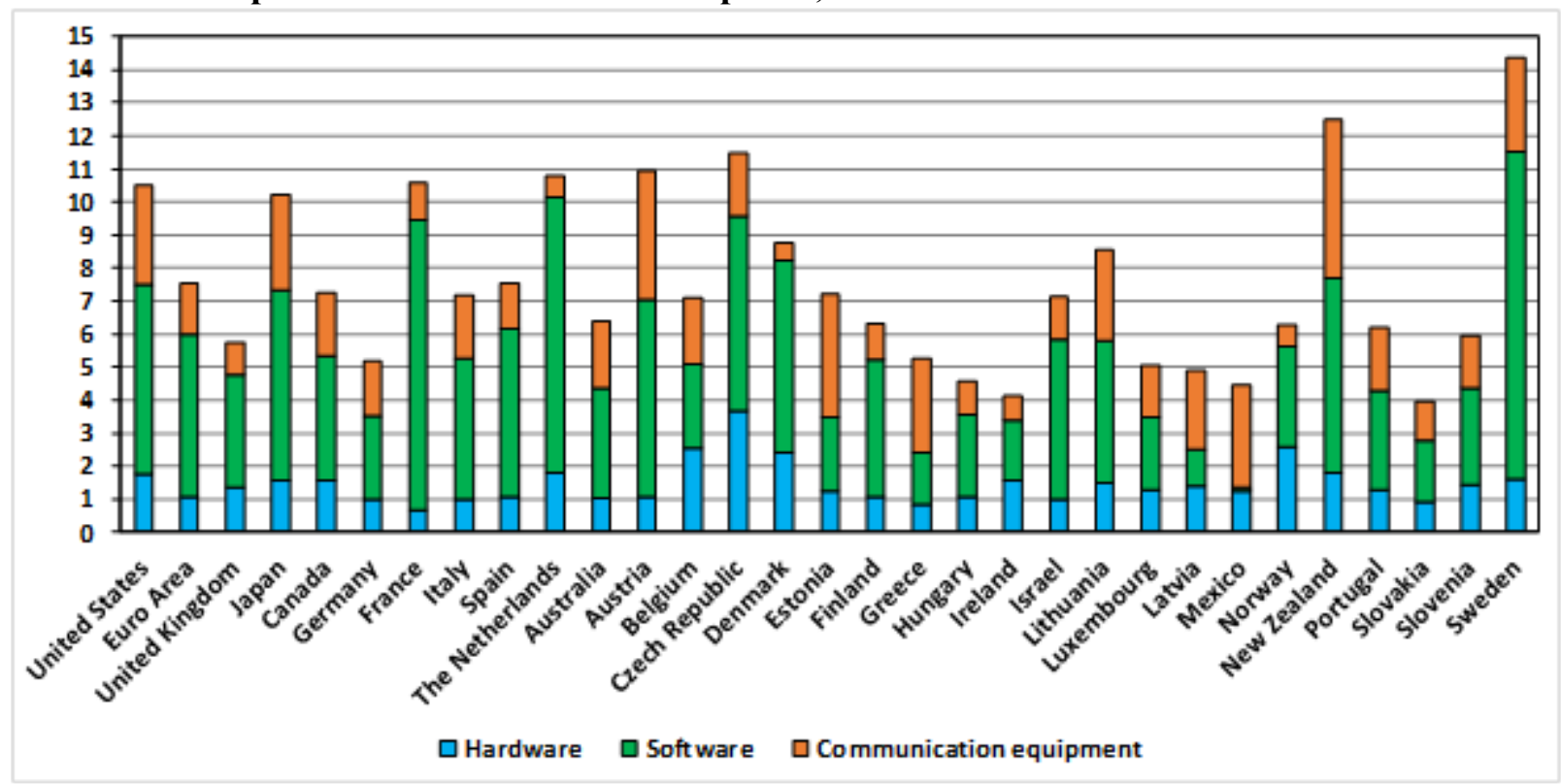

Source: Authors' calculations.

\subsection{Robot diffusion}

Robots can now perform a wide range of tasks, with very little or no human intervention. Unlike ICTs, they are able of flexible movements in three dimensions, which were previously exclusive to human beings.

Graetz and Michael (2018) estimate that the price of industrial robots in six major developed economies (France, Germany, Italy, Sweden, the United Kingdom and the United States) in 1990-2005 fell by about $50 \%$ in nominal terms and $80 \%$ when adjusted for quality. Such a decrease has fueled rapid diffusion in robots in a number of economies.

The diffusion of robots started in the early 70s, first in Japan, followed by Germany (Chart 3). In other countries, robot diffusion started to pick about a decade later. Japan had the highest penetration of robots until 2011, when Germany took the lead. 


\section{Chart 3}

Robot diffusion, 1960-2019

Number of robots per million of hours worked

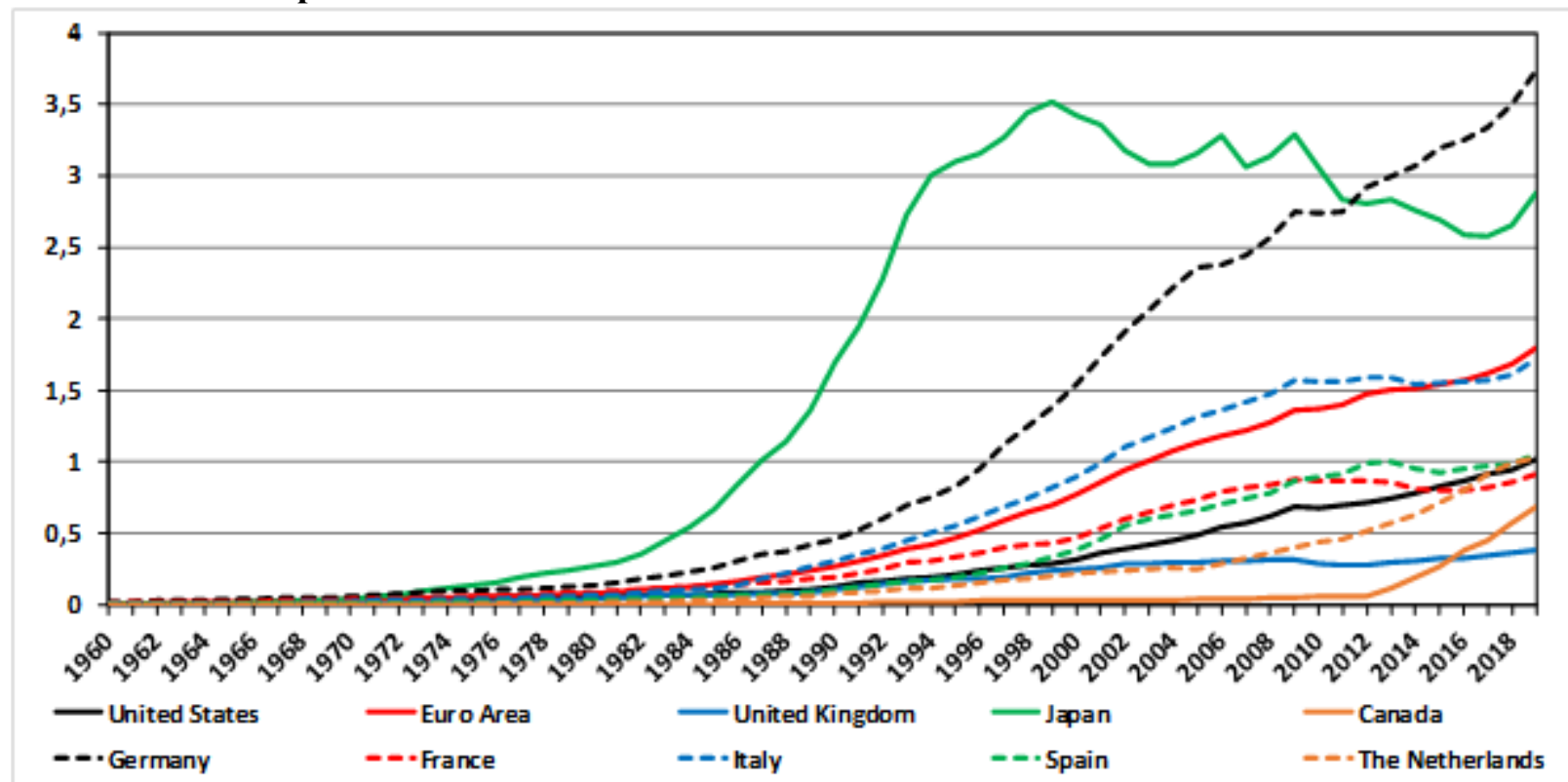

Source: Authors' calculations.

While penetration has been increasing steadily in other countries, the number of robots per millions of hours worked remains lower than in Germany and Japan (Chart 4). Among them, Slovenia, the Czech Republic, Italy, Slovakia and Sweden show the highest values (above 1.5 robots per millions of hours worked).

Robots tend to be concentrated in few manufacturing sectors. Transport equipment account for about $45 \%$ of the world stock of robots, Electronic, electrical and optical equipment for $30 \%$, rubber and plastic for $8 \%$ and Metal products for between $6 \%$. Therefore, the observed patterns of diffusion also reflect country-specific specializations. 


\section{Chart 4}

Robot diffusion, 2019

Number of robots per million of hours worked

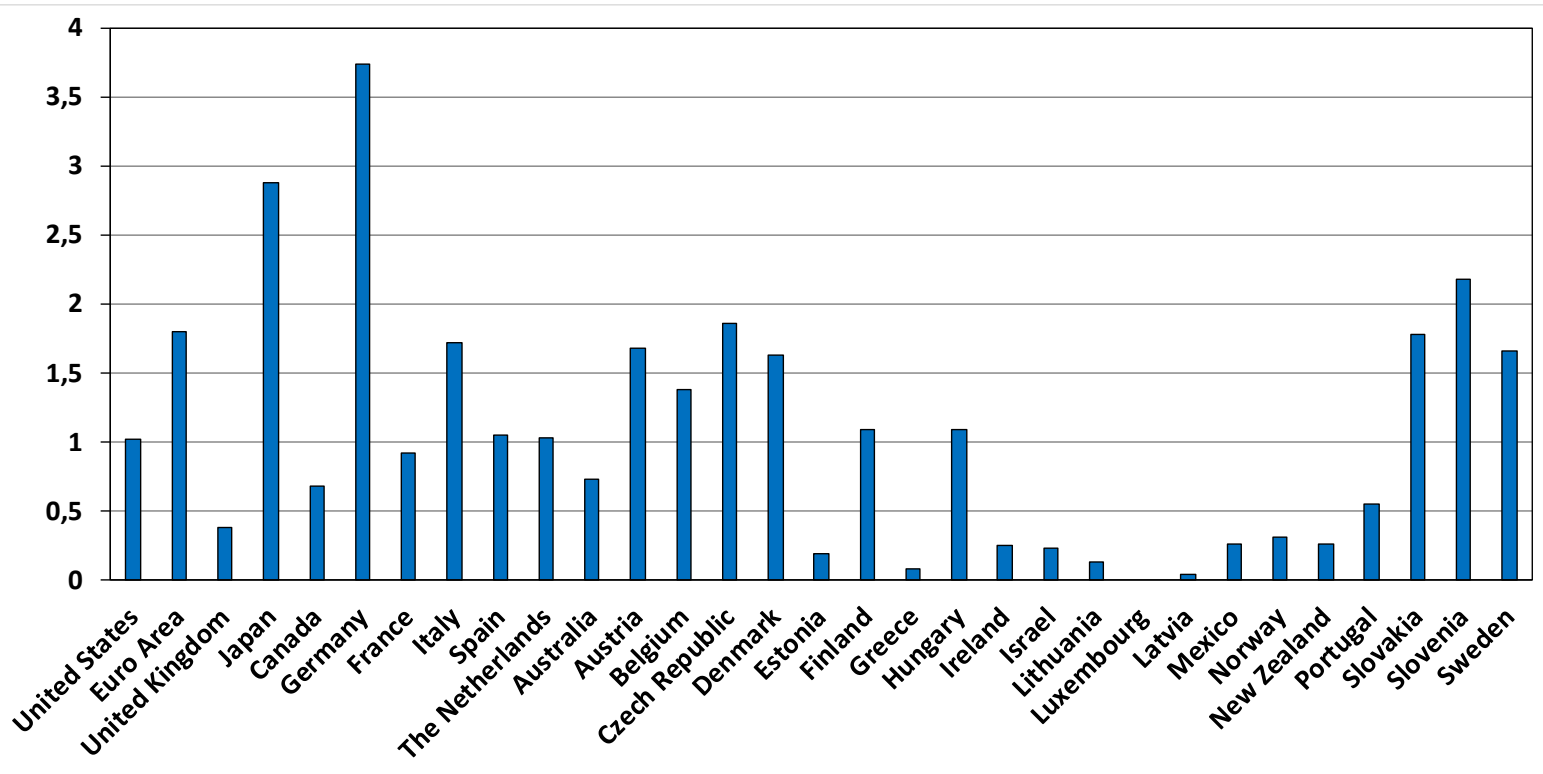

Source: Authors' calculations.

While the effects of robots are a matter of vivid debate among economists (for instance, Brynjolfsson and McAfee, 2014; Autor, 2015; Acemoglu and Restrepo, 2017), only a few empirical studies have looked at their impact on productivity. Among the few exceptions, Graetz and Michael (2018) found that increased robot use contributed approximately 0.36 percentage points to annual labor productivity growth in 17 countries from 1993 to 2007. Our findings below extend their results to a wider set of countries (30) over a longer time period (until 2019).

\section{Growth accounting decomposition}

The methodological section above describes how labor productivity growth can be broken down into different factors through a classical growth accounting approach. More precisely, we distinguish here between the capital deepening channel and the TFP one, and within each of these two main channels three components: ICTs, robots and others for the capital deepening one, and education, robots and others for the TFP one. For the two channels, the component 'others' corresponds to numerous implicit factors such as, for instance, technical progress (not included in ICTs and robots), institutions, or missmeasurement. This decomposition allows us to analyze the factors of productivity growth (4.1.) and the factors of the productivity slowdown (4.2.). We drop this decomposition before 1995 and over the whole 1960-2019 period for the former communist countries ${ }^{9}$ and Israel, their data not being precise enough. The appendix presents detailed results of the growth accounting decomposition concerning the G7 countries (Canada, France, Germany, Italy, Japan, the United Kingdom and the United States), the Euro Area and Spain. ${ }^{10}$

9 These countries are in our dataset the Czech Republic, Estonia, Hungary, Lithuania, Latvia, Slovakia and Slovenia.

10 Same tables for other countries among the 30 ones of our database are available upon request from the authors. 


\subsection{The factors of growth}

Over the whole 1960-2019 period, the main factors contributing to labor productivity growth were TFP, non-ICT non-robot capital deepening and education (Chart 5). The highest average labor productivity growth rates are observed in Ireland and Japan, which can be explained by an initial low level and a catching up process. In contrast, the lowest average labor productivity growth rates are observed in the US and Canada, where initial productivity levels were high, and also in Mexico and New Zealand, which suffer from other productivity brakes: un-adapted institutions for the former and geographical isolation which increases the trade costs for the latter. Other countries are in an intermediate situation. These results are consistent with those of previous analyses (see for instance Bergeaud et al., 2016, 2018).

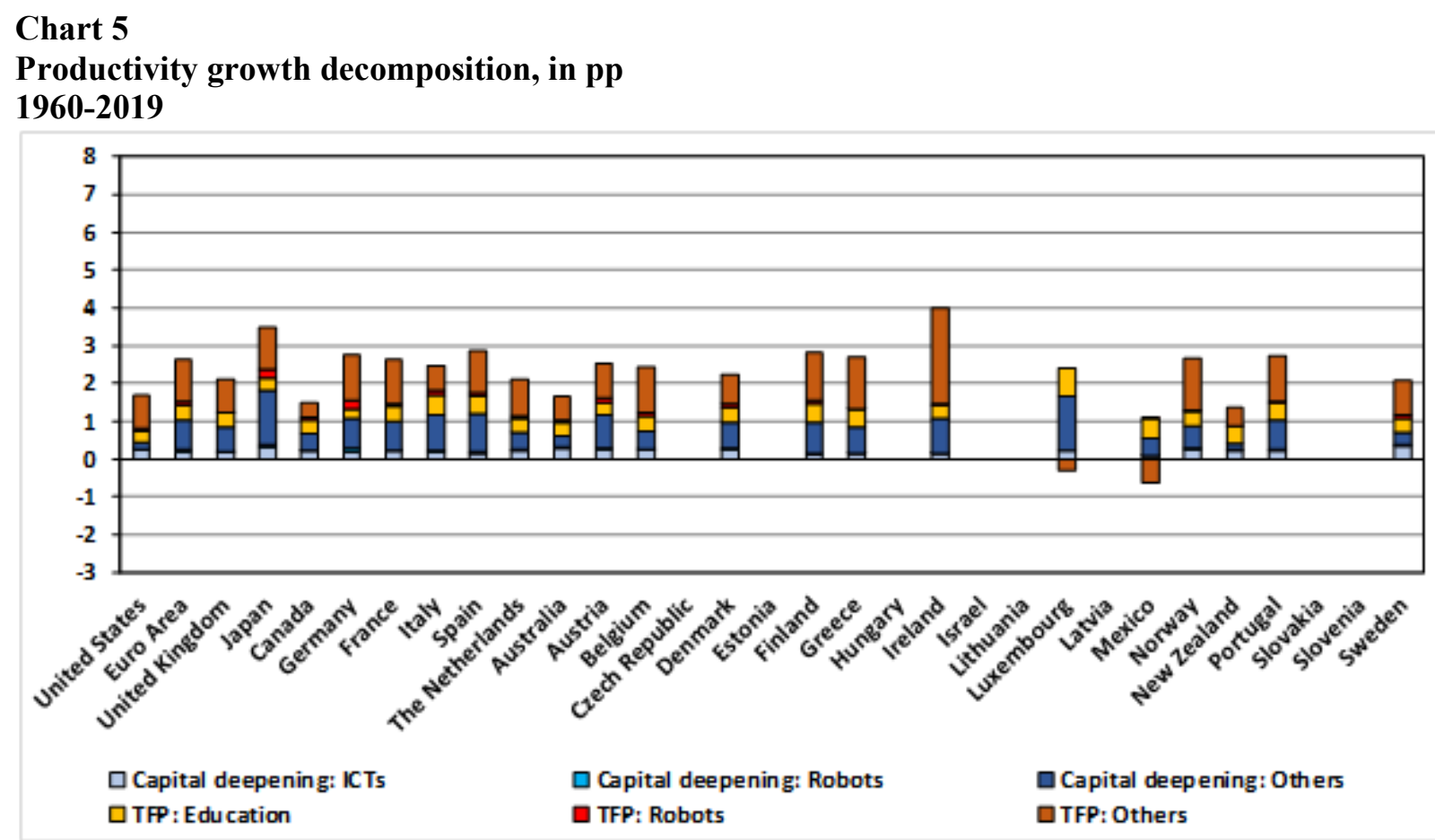

Source: Authors' calculations.

We look at the factors of labor productivity growth over 4 sub-periods: 1960-1975 before the first oil shock, 1975-1995 from the first oil choc to the starting point of the ICT main diffusion period at least in the US (Cf. Jorgenson, 2001, Jorgenson et al., 2006, 2008), 1995-2005 being the highest ICT diffusion sub-period, and 2005-2019 the end of the period including the Great Recession (Charts 6-A to 6-D).

It appears that the contribution of ICTs to capital deepening is low on the four sub-periods. It does not mean that ICT contribution to growth is low, as we do not distinguish the ICT contribution to TFP growth, which may be higher (Byrne et al. 2013; Fernald, 2015). Robot contribution to productivity growth through the two channels (capital deepening and TFP) appears to be significant from the subperiod 1975-1995 in the two main robotized countries, Germany and Japan, from 1995-2005 in France and Italy and in the last sub-period 2005-2019 in several other countries, mainly those which were communist before 1990. Education has a permanent significant contribution to productivity growth in almost all countries. And the main contributions to productivity growth are the other factors of capital deepening and TFP. These two factors contribute globally the most and very significantly from 1975 in Ireland, and from 1995 in the countries previously communist, for the same catching up reason. 
Chart 6

Productivity growth decomposition, in pp

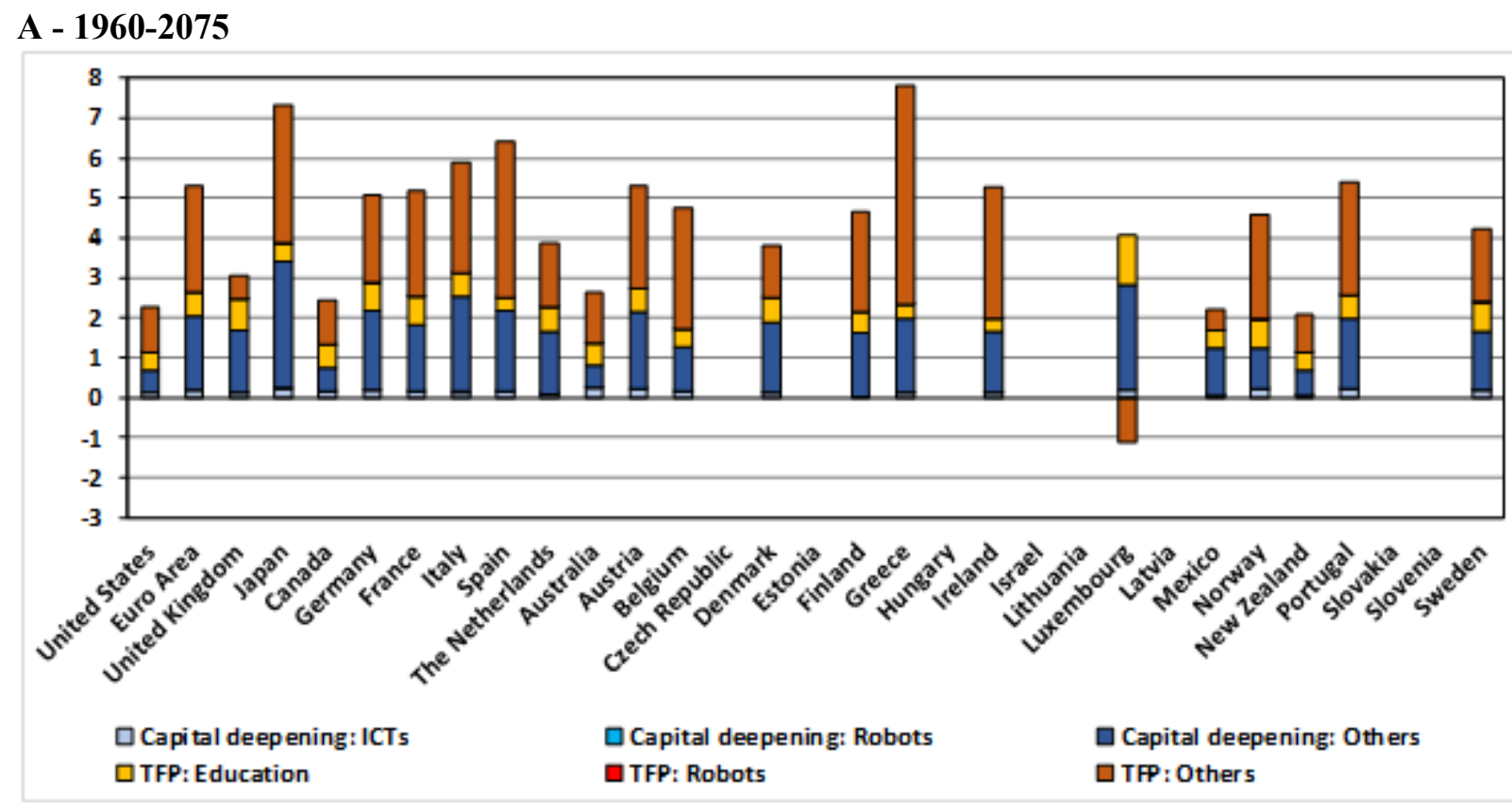

B - 1975-1995

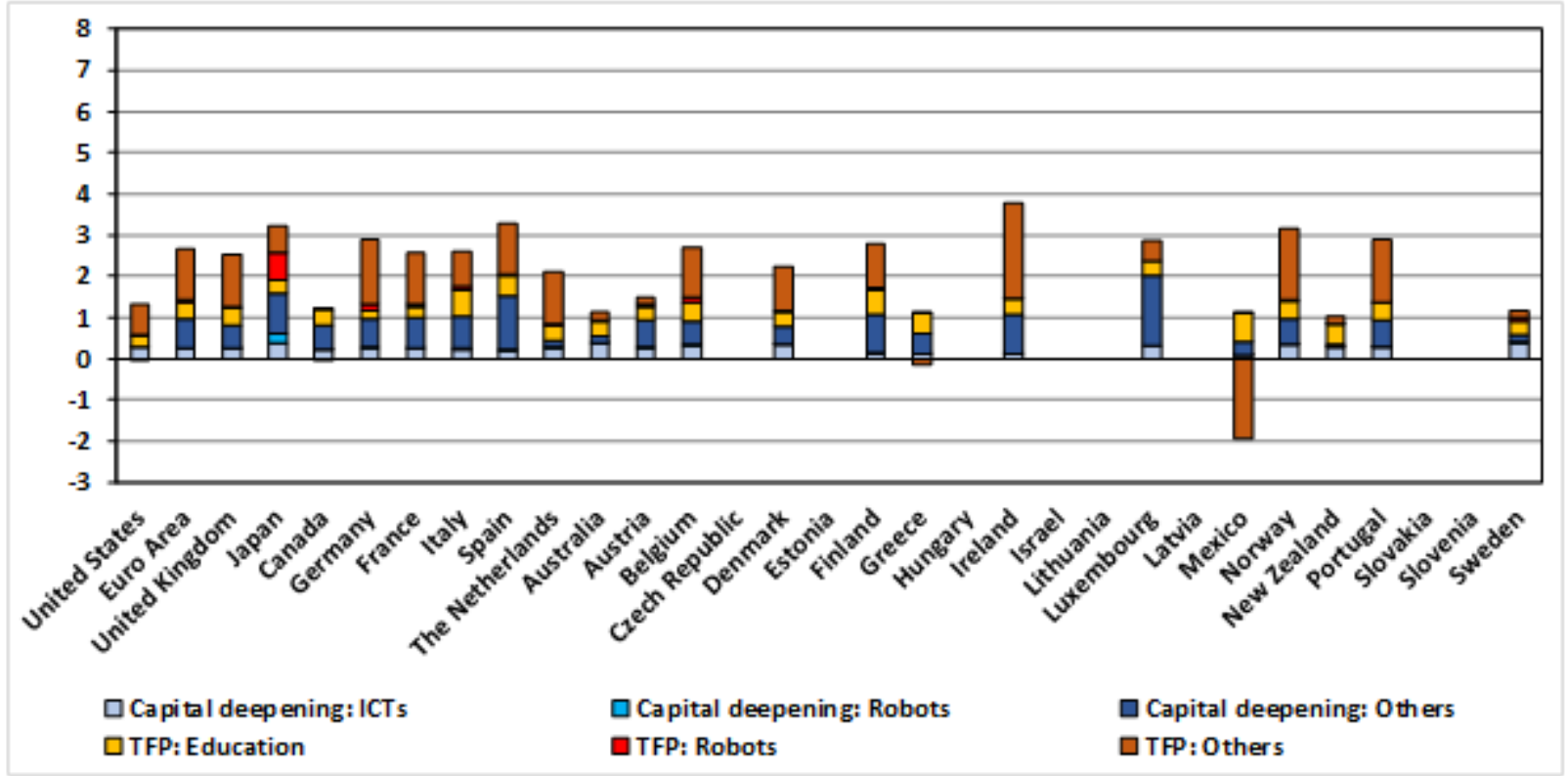




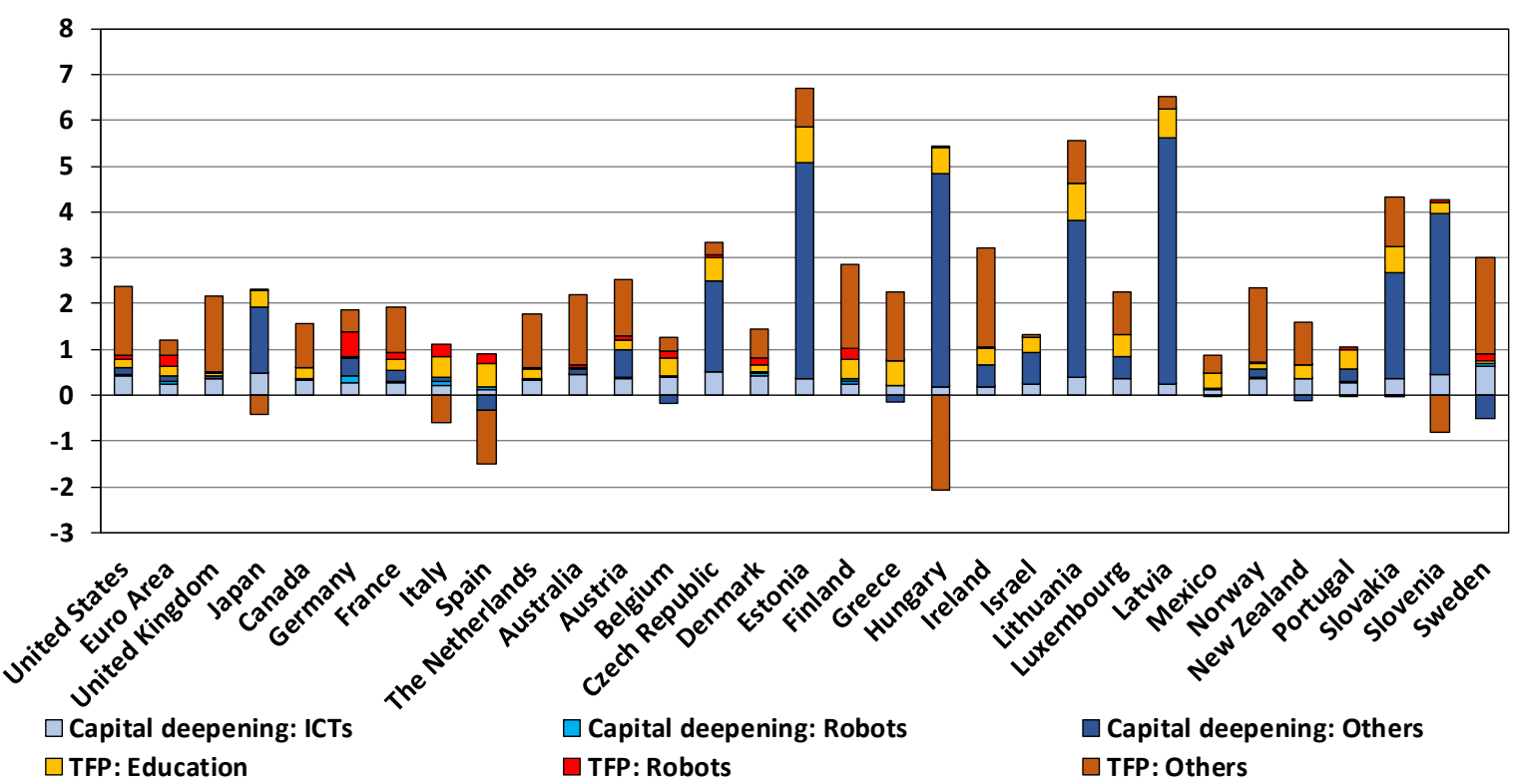

D - 2005-2019

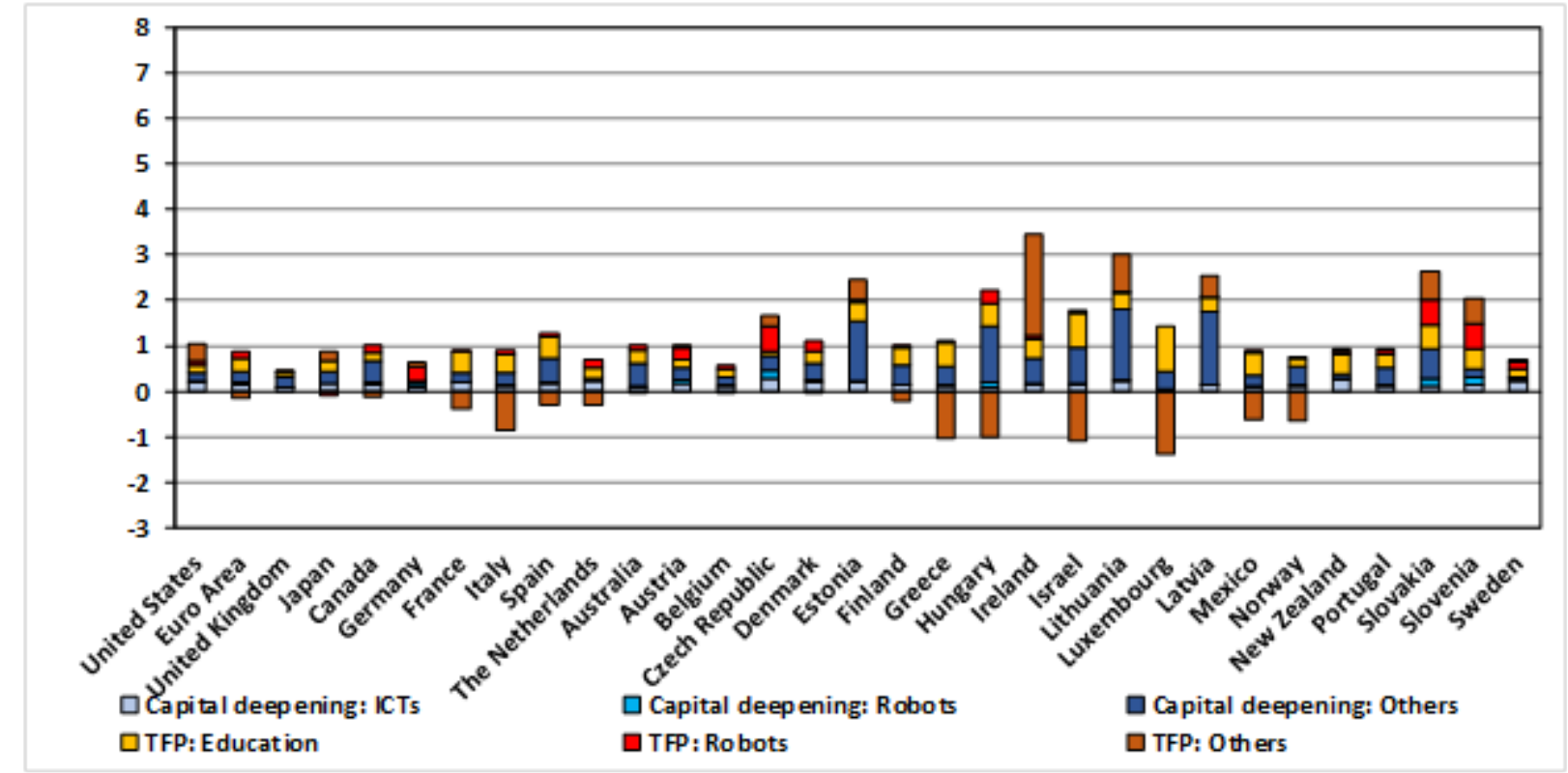

Source: Authors' calculations.

\subsection{The factors of productivity slowdown}

Except for countries that are in a late productivity catching up process, such as Ireland and former communist countries, we observe a general and dramatic productivity slowdown (Charts 6-A to 6-D). This slowdown is mainly explained by a decrease of the contributions of the components 'others' in the capital deepening and the TFP channels. It could correspond to an exhaustion of the favorable impact of the Second industrial revolution as explained by Bergeaud et al. (2018). The digital revolution and Third industrial revolution, to which are linked ICTs and robotization among other elements, are not yet the sources of a productivity revival, even if we could expect from them a large contribution to productivity growth. 
Numerous analyses have stressed that it always takes a long time for the full impact of a technological revolution to be felt in productive activity (see, for example, Brynjolfsson and McAfee, 2014; van Ark, 2016; Branstetter and Sichel, 2017). As Robert Solow famously wrote in a 1987 article in the New York Times, ${ }^{11}$ "You can see the computer age everywhere, but in the productivity statistics". This impatience suggests we have forgotten what happened in previous technological revolutions: the profound changes were only diffused gradually, and their impact on productive performance was not felt until decades later. Paul David (1990) has shown that between 50 and 60 years passed between the invention of a working electric dynamo in 1868 and its full exploitation in production (in the 1920s to 1930s).

As Van Ark (2016) or Inklaar et al. (2020) say, the current pause in the productivity gains from the Third Industrial Revolution could in fact be a period of transition between the creation and installation of new technologies and their full deployment. As with previous technological revolutions, notably the use of electric power, this deployment phase will take time and will require major changes to our institutions and to our methods of production and of management. However, it is already close at hand.

\section{Conclusion}

Growth accounting is the most widely used approach to measure the contribution of Information and Telecommunication Technologies (ICTs) to productivity growth. This paper has contributed to the growth accounting literature by estimating the contribution of ICT-capital and robots to labor productivity growth in 30 countries and the Euro Area over almost six decades (1960-2019), based on a new dataset developed for this purpose.

The main drivers of labor productivity growth over the whole period 1960-2019 period appears to be TFP, non-ICT and non-robot capital deepening, and education. The overall contribution of ICT capital is found out to be small, although we do not estimate its effect on TFP. The contribution of robots to productivity growth through the two channels (capital deepening and TFP) appears to be significant in Germany and Japan in the sub-period 1975-1995, in France and Italy in 1995-2005, and in several Eastern European countries in 2005-19.

Our findings confirm the slowdown in TFP in most countries from at least 1995 onwards. This slowdown is mainly explained in our growth accounting approach by a decrease of the contributions of the components 'others' in the capital deepening and the TFP productivity channels. While several contributions have recently addressed this issue (for examples, Van Ark, 2016; Andrews et al., 2016; Aghion et al., 2009) further analysis appears necessary to explain the cause of such slowdown.

We are still waiting for a large productivity benefit from the third industrial revolution: the digital one. We know from previous industrial revolutions that it may take decades to get a large productivity benefit at the global level from promising inventions and innovations. If we extrapolate that, it could take a long time for the full impact of the digital revolution to be felt in productivity statistics at the global level. If this explanation is the right one, we could benefit in some years or decades from a dramatic productivity revival. Otherwise, developed countries would face with difficulties the numerous challenges of the future. These challenges, which Gordon refers to as headwinds (see for instance, among many papers, Gordon, 2015), include population ageing, climate sustainability, the reduction of public debt and expectation of purchasing power increases. Moreover, without sufficient productivity growth to oil the wheels of the economy, the sustainability of the social systems and the high standard of living of developed countries would be threatened and the political risks to our democracies would inevitably increase.

11 Article entitled "We'd better watch out" published in the New York Times Book Review, 12 July, 1987. 


\section{BIBLIOGRAPHY}

Acemoglu, Daron, Claire Lelarge, and Pascual Restrepo (2020): «Competing with Robots: FirmLevel Evidence from France », American Economic Review, Papers and Proceedings, Vol. 110, pp. $383-388$.

Acemoglu, Daron and Pascual Restrepo (2017): "Robots and Jobs: Evidence from US Labor Markets," NBER working paper 23285.

Aghion, Philippe, Philippe Askenazy, Renaud Bourlès, Gilbert Cette and Nicolas Dromel (2009): "Education, Market Rigidities and Growth", Economics Letters, Vol. 102, No.1, pp 62-65.

Andrews, Dan, Chiara Criscuolo and Peter N. Gal (2016): "The Best versus the Rest: The Global Productivity Slowdown, Divergence across Firms and the Role of Public Policy", OECD Productivity Working Papers, 2016-05, OECD Publishing, Paris.

Autor, David (2005): "Why Are There Still So Many Jobs? The History and Future of Workplace Automation," Journal of Economic Perspectives 29:3, 3-30.

Barro, Robert and Jong-Wha Lee (2010): "A new data set of educational attainment in the world, 1950-2010,” NBER Working Papers, n 15902, National Bureau of Economic Research, Inc.

Bergeaud, Antonin, Gilbert Cette and Rémy Lecat (2016): Productivity trends in advanced countries between 1890 and 2012", The review of Income and Wealth, 62(3), pp. 420-444.

Bergeaud, Antonin, Gilbert Cette and Rémy Lecat (2017): "Total Factor Productivity in Advanced Countries: A Long-term Perspective”, International Productivity Monitor, $N^{\circ} 32$, Spring.

Bergeaud, Antonin, Gilbert Cette and Rémy Lecat (2018): "The role of production factor quality and technology diffusion in twentieth-century productivity growth", Cliometrica, 12 (1), pp. 61-97.

Bergeaud, Antonin, Gilbert Cette and Rémy Lecat (2019): “The Circular Relationship Between Productivity Growth and Real Interest Rates", Banque de France, Working Paper n 734, October.

Branstetter, Lee and Daniel E. Sichel (2017): "The case for an American Productivity Revival", Peterson Institute for International Economics, Policy Brief, No. 17-26, June.

Brynjolfsson, Erik and Andrew McAfee (2014): "The second machine age - Work, progress, and prosperity in a time of brilliant technologies", W. W. Norton \& Company.

Byrne, David, Stephen D. Oliner and Daniel E. Sichel (2013): "Is the Information Technology Revolution Over?", International Productivity Monitor, No. 25, Spring, pp. 20-36.

Cette, Gilbert, Christian Clerc and Léa Bresson (2015): "Contribution of ICT Diffusion to Labour Productivity Growth: The United States, Canada, the Eurozone, and the United Kngdom”, International Productivity Monitor, $\mathrm{N}^{\circ} 28$, Spring.

Cette, Gilbert and Jimmy Lopez (2012): "ICT Demand Behaviour: An International Comparison", Economics of Innovation and New Technology Vol. 21, No. 4, pp. 397-410.

Cette, Gilbert, Jimmy Lopez and Jacques Mairesse (2017): “Upstream Product Marker Regulations, ICT, R\&D and Productivity", The Review of Income and Wealth, $\mathrm{N}^{\circ}$ 63, Sup. 1, February, pp. S68S89. 
Cette, Gilbert, Jimmy Lopez, Giorgio Presidente and Vincenzo Spieza (2019): "Measuring 'indirect' investment in ICT in OECD countries", Economics of Innovation and New Technology, Vol. 28, Issue 4, pp. 348-364.

Colecchia, Alessandra and Paul Schreyer (2002): "ICT Investment and Economic Growth in the 1990s: Is the United States a Unique Case? A Comparative Study of Nine OECD Countries", Review of Economic Dynamics, Vol. 5, No. 2, pp. 408-442, April.

Corrado, Carol A., Charles R. Hulten and Daniel E. Sichel (2006): "Intangible Capital and Economic Growth", Working Paper 11948, NBER Working Paper Series.

Corrado, Carol, Jonathan Haskel, Massimiliano Iommi and Cecilia Jona-Lasinio (2020): "Intangible capital, innovation, and productivity à la Jorgenson evidence from Europe and the United States", Chapter 16 in "Mesuring Economic Growth and Productivity", Edited by Barbara Fraumeny, Elsevier, Academic Press, pp. 363-386.

David, Paul A. (1990): "The Dynamo and the Computer: An Historical Perspective on the Modern Productivity Paradox", American Economic Review, Papers and Proceedings, Vol. 80, No. 2, pp. 355361.

Fernald, John (2015): "Productivity and Potential Output before, during, and after the Great Recession", NBER Macroeconomics Annual, University of Chicago Press, vol. 29(1), pages 1-51.

Gordon, Robert (2015): "Secular Stagnation: A Supply-Side View", American Economic Review, Papers \& Proceedings, 105(5), pp. 54-59.

Graetz, Georg and Guy Michaels (2015): «Robots at work », CEPR, Discussion Paper No. 10477, March.

Graetz, Georg and Guy Michaels (2018): "Robots at work», The Review of Economics and Statistics, Vol. 100, Issue 5, December, pp. 753-768.

Guerrieri, Paolo, Matteo Luciani, and Valentina Meliciani (2011): “The Determinants of Investment in Information and Communication Technologies", Economics of Innovation and New Technology Vol. 20, Number 4, pp. 387-403.

Inklaar, Robert, Kirsten JÄger, Mary O'Mahony and Bart van Ark (2020): "European productivity in the digital age: evidence from EU KLEMS", Chapter 5 in "Mesuring Economic Growth and Productivity", Edited by Barbara Fraumeny, Elsevier, Academic Press, pp. 75-94.

Jordà, Òscar, Katharina Knoll, Dmitry Kuvshinov, Moritz Schularick, and Alan M Taylor (2019): "The Rate of Return on Everything, 1870-2015", The Quarterly Journal of Economics, 04 2019, 134 (3), pp. 1225-1298.

Jorgenson, Dale (1963): "Capital theory and investment behavior", The American Economic Review 53 (2), pp. 247-259.

Jorgenson, Dale (2001): "Information technology and the US economy", The American Economic Review, Vol. 91, March, No. 1, pp. 1-32.

Jorgenson, Dale, Mun Ho and Kevin Stiroh (2006): "Potential Growth of the US Economy: Will the Productivity Resurgence Continue?", Business Economy, January.

Jorgenson, Dale, Mun Ho and Kevin Stiroh (2008): "A Retrospective Look at the U.S. Productivity Growth Resurgence", Journal of Economic Perspectives, Vol. 22, Winter, No. 1, pp. 3-24. 
Jorgenson, Dale W. and Kevin J. Stiroh (2000): "Raising the Speed Limit: US Economic Growth in the

Information Age", Brookings Papers on Economic Activity, Economic Studies Program, The Brookings Institution, Vol. 31(1), pp. 125-236.

Krueger, Alan and Mikael Lindahl (2001): "Education for Growth: Why and For Whom?", Journal of Economic Literature, American Economic Association, vol. 39(4), December, pp. 1101-1136.

OECD (2019), OECD Compendium of Productivity Indicators 2019, OECD Publishing, Paris.

OECD (2018): Main Economic Indicators.

OECD (2001): Measuring Productivity, OECD Publishing.

OECD (2009): Measuring Capital: OECD Manual 2009, Second Edition, OECD Publishing.

Oliner, Stephen D. and Daniel E. Sichel (2000): "The Resurgence of Growth in the Late 1990s: Is Information Technology the Story?" Journal of Economic Perspectives, 14, pp. 3-22.

Oliner, Stephen D. and Daniel E. Sichel (2002): "Information Technology and Productivity: Where Are We Now and Where Are We Going?", Federal Reserve Bank of Atlanta Review, 87(3), pp. 15-44

O'Mahony, Mary and Michela Vecchi (2005): “Quantifying the Impact of ICT on Output Growth: A Heterogeneous Dymamic Panel Approach”, Economica, 72 (288), pp. 615-633.

Oulton, Nicholas (2002): "ICT and Productivity Growth in the United Kingdom", Oxford Review of Economic Policy, Oxford University Press, Vol. 18(3), pp. 363-379.

Presidente, Giorgio (2019): "Determinants and impact of automation: An analysis of robots' adoption in OECD countries", OECD Digital Economy Papers, No. 277, OECD Publishing, Paris.

Schreyer, Paul (2000): "The Contribution of Information and Communication Technology to Output Growth: A Study on the G7 Countries", OECD Science, Technology and Industry Working Papers 2000/2, OECD.

Solow, Robert (1956): “A contribution to the theory of growth", Quarterly Journal of economics 70 (1), pp. 65-94.

Solow, Robert (1957): “Technical change and aggregate production function", Review of Economics and Statistics 39 (3), pp. 312-320.

Solow, Robert (1959): "Investment and Technical Change", in Mathematical Methods in the Social Sciences, Stanford.

Solow, Robert (1962): “Technical Progress, Capital Formation, and Economic Growth", The American Economic Review, Proceedings, May, pp. 76-86.

Soto, Marcelo (2002): "Rediscovering Education in Growth Regressions," OECD Development Centre Working Papers 202, OECD Publishing.

Spiezia, Vincenzo (2012): "ICT investments and productivity: Measuring the contribution of ICTS to growth", OECD Journal: Economic Studies, vol. 2012/1. 
Timmer, Marcel P., Robert Inklaar, Mary O'Mahony and Bart van Ark (2010): "Economic Growth in Europe: A Comparative Industry Perspective”, Cambridge University Press.

Timmer, Marcel, Robert Inklaar, Mary O'Mahony, and Bart Van Ark (2011): "Productivity and Economic Growth in Europe: A Comparative Industry Perspective", International Productivity Monitor, Number 21, Spring, pp. 3-23.

Van Ark, Bart (2016): "The productivity paradox of the new digital economy", International Productivity Monitor, No. 31, Fall, pp. 3-18.

Van Ark, Bart, Mary O'Mahony and Marcel Timmer (2008): "The Productivity Gap between Europe and the United States: Trends and Causes", Journal of Economic Perspectives, Vol. 22, No. 1, pp. 25-44.

Van Ark, Bart, Johanna Melka, Nanno Mulder, Marcel Timmer and Gerard Ypma (2002): "ICT Investment and Growth Accounts for the European Union, 1980-2000", final report on ICT and Growth Accounting prepared for the DG Economics and Finance of the European Commission, Brussels.

Van Leeuwen, Bas and Jieli van Leeuwen-Li (2014): "Education since 1820", In: J.L. van Zanden et al. (eds.), How Was Life?: Global Well-Being since 1820, OECD Publishing, pp. 88-101. 


\section{Appendix}

Results of growth accounting decomposition for some countries and the Euro Area ${ }^{12}$ GDP growth (in \%) and contributions (in pp)

Table A1 - United States

\begin{tabular}{|c|c|c|c|c|c|}
\hline GDP growth (in \%) and contributions (in pp) & Period 1 & Period 2 & Period 3 & Period 4 & Period 5 \\
\hline United States & $1960 \quad 1975$ & $1975 \quad 1995$ & $1995 \quad 2005$ & $2005 \quad 2019$ & $1960 \quad 2019$ \\
\hline GDP (1) & 3,66 & 3,16 & 3,39 & 1,76 & 2,99 \\
\hline Hours (2) & 1,38 & 1,88 & 1,01 & 0,71 & 1,33 \\
\hline Productivity (3) $=(1)-(2)$ & 2,28 & 1,29 & 2,38 & 1,05 & 1,67 \\
\hline Capital deepening (4) & 0,67 & 0,25 & 0,58 & 0,40 & 0,45 \\
\hline ICT capital total $(5)=(6)+(7)+(8)$ & 0,11 & 0,27 & 0,43 & 0,20 & 0,24 \\
\hline Hardware (6) & 0,06 & 0,15 & 0,21 & 0,05 & 0,11 \\
\hline Software and databases (7) & 0,03 & 0,09 & 0,14 & 0,11 & 0,09 \\
\hline Telecommunication eqpt (8) & 0,03 & 0,04 & 0,07 & 0,04 & 0,04 \\
\hline Robots (9) & 0,00 & 0,01 & 0,03 & 0,03 & 0,02 \\
\hline Non ICT capital and non robots capital $(10)=(4)-(5)-(9)$ & 0,55 & $-0,03$ & 0,13 & 0,16 & 0,19 \\
\hline $\operatorname{TFP}(11)=(3)-(4)$ & 1,61 & 1,03 & 1,79 & 0,65 & 1,22 \\
\hline Education (12) & 0,45 & 0,27 & 0,20 & 0,17 & 0,28 \\
\hline Robotisation (13) & 0,01 & 0,03 & 0,08 & 0,10 & 0,05 \\
\hline Residual $(14)=(11)-(12)-(13)$ & 1,15 & 0,73 & 1,51 & 0,38 & 0,89 \\
\hline
\end{tabular}

\section{Table A2 - Euro Area}

\begin{tabular}{|c|c|c|c|c|c|}
\hline GDP growth (in \%) and contributions (in pp) & Period 1 & Period 2 & Period 3 & Period 4 & Period 5 \\
\hline ZONE EURO 2 & $1960 \quad 1975$ & $1975 \quad 1995$ & $1995 \quad 2005$ & $2005 \quad 2019$ & $1960 \quad 2019$ \\
\hline GDP (1) & 4,60 & 2,44 & 2,12 & 1,09 & 2,61 \\
\hline Hours (2) & $-0,71$ & $-0,22$ & 0,93 & 0,37 & $-0,01$ \\
\hline Productivity (3) $=(1)-(2)$ & 5,31 & 2,66 & 1,19 & 0,72 & 2,63 \\
\hline Capital deepening (4) & 2,03 & 0,97 & 0,43 & 0,42 & 1,02 \\
\hline ICT capital total $(5)=(6)+(7)+(8)$ & 0,17 & 0,23 & 0,24 & 0,14 & 0,19 \\
\hline Hardware (6) & 0,11 & 0,12 & 0,11 & 0,03 & 0,09 \\
\hline Software and databases (7) & 0,03 & 0,09 & 0,10 & 0,09 & 0,08 \\
\hline Telecommunication eqpt (8) & 0,03 & 0,02 & 0,03 & 0,02 & 0,03 \\
\hline Robots (9) & 0,00 & 0,03 & 0,08 & 0,05 & 0,04 \\
\hline Non ICT capital and non robots capital $(10)=(4)-(5)-(9)$ & 1,86 & 0,71 & 0,11 & 0,24 & 0,79 \\
\hline $\operatorname{TFP}(11)=(3)-(4)$ & 3,28 & 1,69 & 0,77 & 0,30 & 1,61 \\
\hline Education (12) & 0,59 & 0,38 & 0,21 & 0,31 & 0,39 \\
\hline Robotisation (13) & 0,01 & 0,08 & 0,24 & 0,15 & 0,12 \\
\hline Residual (14) = (11)-(12)-(13) & 2,68 & 1,23 & 0,32 & $-0,16$ & 1,10 \\
\hline
\end{tabular}

Table A3 - United Kingdom

\begin{tabular}{|c|c|c|c|c|c|}
\hline GDP growth (in \%) and contributions (in pp) & Period 1 & Period 2 & Period 3 & Period 4 & Period 5 \\
\hline United Kingdom & $1960 \quad 1975$ & $1975 \quad 1995$ & $1995 \quad 2005$ & $2005 \quad 2019$ & $1960 \quad 2019$ \\
\hline GDP (1) & 2,35 & 2,28 & 3,05 & 1,36 & 2,21 \\
\hline Hours (2) & $-0,70$ & $-0,23$ & 0,89 & 0,91 & 0,11 \\
\hline Productivity $(3)=(1)-(2)$ & 3,04 & 2,52 & 2,16 & 0,45 & 2,10 \\
\hline Capital deepening (4) & 1,69 & 0,79 & 0,41 & 0,32 & 0,84 \\
\hline ICT capital total $(5)=(6)+(7)+(8)$ & 0,11 & 0,24 & 0,35 & 0,08 & 0,19 \\
\hline Hardware (6) & 0,07 & 0,09 & 0,22 & 0,03 & 0,09 \\
\hline Software and databases (7) & 0,03 & 0,14 & 0,08 & 0,04 & 0,08 \\
\hline Telecommunication eqpt (8) & 0,00 & 0,01 & 0,05 & 0,01 & 0,01 \\
\hline Robots (9) & 0,00 & 0,01 & 0,01 & 0,01 & 0,01 \\
\hline Non ICT capital and non robots capital $(10)=(4)-(5)-(9)$ & 1,58 & 0,54 & 0,05 & 0,23 & 0,65 \\
\hline $\operatorname{TFP}(11)=(3)-(4)$ & 1,35 & 1,72 & 1,75 & 0,13 & 1,26 \\
\hline Education (12) & 0,76 & 0,42 & 0,06 & 0,10 & 0,37 \\
\hline Robotisation (13) & 0,00 & 0,03 & 0,04 & 0,02 & 0,02 \\
\hline Residual $(14)=(11)-(12)-(13)$ & 0,58 & 1,27 & 1,65 & 0,02 & 0,86 \\
\hline
\end{tabular}

12 Same tables concerning other countries of our dataset are available upon request from the authors. 
Table A4 - Japan

\begin{tabular}{|c|c|c|c|c|c|}
\hline GDP growth (in \%) and contributions (in pp) & Period 1 & Period 2 & Period 3 & Period 4 & Period 5 \\
\hline Japan & $1960 \quad 1975$ & $1975 \quad 1995$ & $1995 \quad 2005$ & $2005 \quad 2019$ & $1960 \quad 2019$ \\
\hline GDP (1) & 7,90 & 3,70 & 1,13 & 0,65 & 3,61 \\
\hline Hours (2) & 0,57 & 0,49 & $-0,75$ & $-0,14$ & 0,15 \\
\hline Productivity $(3)=(1)-(2)$ & 7,33 & 3,21 & 1,89 & 0,79 & 3,46 \\
\hline Capital deepening (4) & 3,40 & 1,58 & 1,92 & 0,42 & 1,82 \\
\hline ICT capital total $(5)=(6)+(7)+(8)$ & 0,22 & 0,39 & 0,47 & 0,16 & 0,30 \\
\hline Hardware (6) & 0,15 & 0,23 & 0,23 & 0,03 & 0,16 \\
\hline Software and databases (7) & 0,01 & 0,09 & 0,17 & 0,10 & 0,09 \\
\hline Telecommunication eqpt (8) & 0,06 & 0,07 & 0,06 & 0,03 & 0,06 \\
\hline Robots (9) & 0,01 & 0,21 & 0,01 & $-0,02$ & 0,06 \\
\hline Non ICT capital and non robots capital $(10)=(4)-(5)-(9)$ & 3,17 & 0,98 & 1,44 & 0,28 & 1,46 \\
\hline $\operatorname{TFP}(11)=(3)-(4)$ & 3,92 & 1,64 & $-0,03$ & 0,37 & 1,64 \\
\hline Education (12) & 0,42 & 0,32 & 0,37 & 0,22 & 0,33 \\
\hline Robotisation (13) & 0,04 & 0,66 & 0,02 & $-0,06$ & 0,20 \\
\hline Residual (14) = (11)-(12)-(13) & 3,47 & 0,66 & $-0,43$ & 0,22 & 1,11 \\
\hline
\end{tabular}

\section{Table A5 - Canada}

\begin{tabular}{|c|c|c|c|c|c|}
\hline GDP growth (in \%) and contributions (in pp) & Period 1 & Period 2 & Period 3 & Period 4 & Period 5 \\
\hline Canada & 19601975 & $1975 \quad 1995$ & $1995 \quad 2005$ & $2005 \quad 2019$ & $1960 \quad 2019$ \\
\hline GDP (1) & 4,66 & 2,67 & 3,24 & 1,75 & 3,05 \\
\hline Hours (2) & 2,24 & 1,53 & 1,68 & 0,86 & 1,58 \\
\hline Productivity (3) = (1)-(2) & 2,42 & 1,14 & 1,56 & 0,89 & 1,48 \\
\hline Capital deepening (4) & 0,74 & 0,79 & 0,35 & 0,66 & 0,67 \\
\hline ICT capital total $(5)=(6)+(7)+(8)$ & 0,15 & 0,23 & 0,34 & 0,13 & 0,20 \\
\hline Hardware (6) & 0,11 & 0,13 & 0,20 & 0,04 & 0,12 \\
\hline Software and databases (7) & 0,01 & 0,07 & 0,09 & 0,07 & 0,06 \\
\hline Telecommunication eqpt (8) & 0,03 & 0,03 & 0,05 & 0,02 & 0,03 \\
\hline Robots (9) & 0,00 & 0,00 & 0,00 & 0,06 & 0,02 \\
\hline Non ICT capital and non robots capital $(10)=(4)-(5)-(9)$ & 0,59 & 0,56 & 0,01 & 0,47 & 0,45 \\
\hline $\operatorname{TFP}(11)=(3)-(4)$ & 1,67 & 0,35 & 1,20 & 0,23 & 0,80 \\
\hline Education (12) & 0,57 & 0,40 & 0,23 & 0,18 & 0,36 \\
\hline Robotisation (13) & 0,00 & 0,00 & 0,01 & 0,18 & 0,05 \\
\hline Residual (14) = (11)-(12)-(13) & 1,11 & $-0,06$ & 0,96 & $-0,14$ & 0,39 \\
\hline
\end{tabular}

Table A6 - Germany

\begin{tabular}{|c|c|c|c|c|c|}
\hline GDP growth (in \%) and contributions (in pp) & Period 1 & Period 2 & Period 3 & Period 4 & Period 5 \\
\hline Germany & $1960 \quad 1975$ & $1975 \quad 1995$ & $1995 \quad 2005$ & $2005 \quad 2019$ & $1960 \quad 2019$ \\
\hline GDP (1) & 3,68 & 2,47 & 1,20 & 1,52 & 2,33 \\
\hline Hours (2) & $-1,41$ & $-0,42$ & $-0,67$ & 0,86 & $-0,41$ \\
\hline Productivity (3) = (1)-(2) & 5,09 & 2,89 & 1,87 & 0,65 & 2,74 \\
\hline Capital deepening (4) & 2,16 & 0,96 & 0,80 & 0,23 & 1,07 \\
\hline ICT capital total $(5)=(6)+(7)+(8)$ & 0,19 & 0,24 & 0,26 & 0,07 & 0,19 \\
\hline Hardware (6) & 0,13 & 0,15 & 0,14 & 0,02 & 0,11 \\
\hline Software and databases (7) & 0,02 & 0,06 & 0,07 & 0,04 & 0,04 \\
\hline Telecommunication eqpt (8) & 0,04 & 0,03 & 0,05 & 0,01 & 0,03 \\
\hline Robots (9) & 0,01 & 0,05 & 0,17 & 0,10 & 0,08 \\
\hline Non ICT capital and non robots capital $(10)=(4)-(5)-(9)$ & 1,97 & 0,68 & 0,37 & 0,05 & 0,80 \\
\hline $\operatorname{TFP}(11)=(3)-(4)$ & 2,93 & 1,93 & 1,06 & 0,42 & 1,68 \\
\hline Education (12) & 0,69 & 0,20 & 0,03 & 0,01 & 0,25 \\
\hline Robotisation (13) & 0,02 & 0,15 & 0,53 & 0,32 & 0,24 \\
\hline Residual (14) = (11)-(12)-(13) & 2,22 & 1,58 & 0,50 & 0,09 & 1,19 \\
\hline
\end{tabular}


Table A7 - France

\begin{tabular}{|c|c|c|c|c|c|}
\hline GDP growth (in \%) and contributions (in pp) & Period 1 & Period 2 & Period 3 & Period 4 & Period 5 \\
\hline France & $1960 \quad 1975$ & $1975 \quad 1995$ & $1995 \quad 2005$ & $2005 \quad 2019$ & $1960 \quad 2019$ \\
\hline GDP (1) & 4,99 & 2,38 & 2,28 & 1,13 & 2,73 \\
\hline Hours (2) & $-0,18$ & $-0,18$ & 0,36 & 0,61 & 0,10 \\
\hline Productivity $(3)=(1)-(2)$ & 5,17 & 2,56 & 1,92 & 0,52 & 2,63 \\
\hline Capital deepening (4) & 1,80 & 1,00 & 0,53 & 0,41 & 0,98 \\
\hline ICT capital total $(5)=(6)+(7)+(8)$ & 0,15 & 0,24 & 0,26 & 0,19 & 0,21 \\
\hline Hardware (6) & 0,06 & 0,07 & 0,06 & 0,01 & 0,05 \\
\hline Software and databases (7) & 0,08 & 0,16 & 0,18 & 0,16 & 0,14 \\
\hline Telecommunication eqpt (8) & 0,01 & 0,01 & 0,02 & 0,02 & 0,01 \\
\hline Robots (9) & 0,00 & 0,02 & 0,04 & 0,01 & 0,02 \\
\hline Non ICT capital and non robots capital $(10)=(4)-(5)-(9)$ & 1,65 & 0,75 & 0,23 & 0,21 & 0,76 \\
\hline $\operatorname{TFP}(11)=(3)-(4)$ & 3,37 & 1,56 & 1,39 & 0,11 & 1,65 \\
\hline Education (12) & 0,72 & 0,25 & 0,26 & 0,45 & 0,42 \\
\hline Robotisation (13) & 0,01 & 0,06 & 0,13 & 0,04 & 0,06 \\
\hline Residual (14) = (11)-(12)-(13) & 2,64 & 1,25 & 1,00 & $-0,38$ & 1,17 \\
\hline
\end{tabular}

Table A8 - Italy

\begin{tabular}{|c|c|c|c|c|c|}
\hline GDP growth (in \%) and contributions (in pp) & Period 1 & Period 2 & Period 3 & Period 4 & Period 5 \\
\hline Italy & 19601975 & 19751995 & $1995 \quad 2005$ & $2005 \quad 2019$ & $1960 \quad 2019$ \\
\hline GDP (1) & 4,75 & 2,58 & 1,47 & $-0,06$ & 2,32 \\
\hline Hours (2) & $-1,13$ & $-0,03$ & 0,96 & $-0,09$ & $-0,15$ \\
\hline Productivity $(3)=(1)-(2)$ & 5,87 & 2,61 & 0,51 & 0,03 & 2,47 \\
\hline Capital deepening (4) & 2,53 & 1,04 & 0,37 & 0,39 & 1,15 \\
\hline ICT capital total $(5)=(6)+(7)+(8)$ & 0,13 & 0,23 & 0,20 & 0,11 & 0,17 \\
\hline Hardware (6) & 0,09 & 0,10 & 0,09 & 0,02 & 0,08 \\
\hline Software and databases (7) & 0,02 & 0,10 & 0,09 & 0,06 & 0,07 \\
\hline Telecommunication eqpt (8) & 0,02 & 0,02 & 0,02 & 0,02 & 0,02 \\
\hline Robots (9) & 0,00 & 0,04 & 0,09 & 0,03 & 0,04 \\
\hline Non ICT capital and non robots capital $(10)=(4)-(5)-(9)$ & 2,40 & 0,77 & 0,09 & 0,26 & 0,94 \\
\hline $\operatorname{TFP}(11)=(3)-(4)$ & 3,34 & 1,57 & 0,14 & $-0,36$ & 1,32 \\
\hline Education (12) & 0,58 & 0,61 & 0,46 & 0,41 & 0,53 \\
\hline Robotisation (13) & 0,01 & 0,11 & 0,27 & 0,10 & 0,12 \\
\hline Residual $(14)=(11)-(12)-(13)$ & 2,75 & 0,84 & $-0,59$ & $-0,86$ & 0,67 \\
\hline
\end{tabular}

Table A9 - Spain

\begin{tabular}{|c|c|c|c|c|c|}
\hline GDP growth (in \%) and contributions (in pp) & Period 1 & Period 2 & Period 3 & Period 4 & Period 5 \\
\hline Spain & $1960 \quad 1975$ & $1975 \quad 1995$ & $1995 \quad 2005$ & $2005 \quad 2019$ & $1960 \quad 2019$ \\
\hline GDP (1) & 6,55 & 2,30 & 3,62 & 1,05 & 3,31 \\
\hline Hours (2) & 0,13 & $-0,96$ & 4,25 & 0,07 & 0,44 \\
\hline Productivity $(3)=(1)-(2)$ & 6,42 & 3,26 & $-0,63$ & 0,99 & 2,87 \\
\hline Capital deepening (4) & 2,16 & 1,51 & $-0,13$ & 0,71 & 1,21 \\
\hline ICT capital total $(5)=(6)+(7)+(8)$ & 0,13 & 0,19 & 0,13 & 0,18 & 0,16 \\
\hline Hardware (6) & 0,09 & 0,10 & 0,07 & 0,03 & 0,08 \\
\hline Software and databases (7) & 0,01 & 0,06 & 0,06 & 0,12 & 0,06 \\
\hline Telecommunication eqpt (8) & 0,03 & 0,03 & 0,00 & 0,02 & 0,02 \\
\hline Robots (9) & 0,00 & 0,01 & 0,06 & 0,03 & 0,02 \\
\hline Non ICT capital and non robots capital $(10)=(4)-(5)-(9)$ & 2,03 & 1,31 & $-0,32$ & 0,51 & 1,02 \\
\hline $\operatorname{TFP}(11)=(3)-(4)$ & 4,26 & 1,76 & $-0,50$ & 0,27 & 1,66 \\
\hline Education (12) & 0,33 & 0,50 & 0,51 & 0,48 & 0,46 \\
\hline Robotisation (13) & 0,01 & 0,04 & 0,19 & 0,10 & 0,08 \\
\hline Residual $(14)=(11)-(12)-(13)$ & 3,92 & 1,21 & $-1,19$ & $-0,30$ & 1,13 \\
\hline
\end{tabular}

